\title{
Water Management Effects on Trace Gas Emissions under Greenhouse Conditions from Direct-Seeded Hybrid Rice in a Silt-Loam Soil
}

\author{
Diego Della Lunga ${ }^{1 *}$, Kristofor R Brye ${ }^{2}$, Trenton $L$ Roberts ${ }^{3}$ and Shelby G Lebeau ${ }^{1}$ \\ ${ }^{1}$ Graduate Student, Department of Crop, Soil, and Environmental Sciences, University of Arkansas, Fayetteville, USA \\ ${ }^{2}$ University Professor of Applied Soil Physics and Pedology, Department of Crop, Soil, and Environmental Sciences, \\ University of Arkansas, Fayetteville, USA \\ ${ }^{3}$ Associate Professor of Soil Fertility/Soil Testing, Department of Crop, Soil, and Environmental Sciences, University of \\ Arkansas, Fayetteville, USA
}

\begin{abstract}
Water management regimes influence greenhouse gas emissions in rice (Oryza sativa L.) production. The objective of this study was to quantify methane $\left(\mathrm{CH}_{4}\right)$, nitrous oxide $\left(\mathrm{N}_{2} \mathrm{O}\right)$, and carbon dioxide $\left(\mathrm{CO}_{2}\right)$ under direct-seeded conditions in the greenhouse to evaluate the effects of water regime on fluxes and growing-season-long emissions. Research was conducted during 2019 using a hybrid rice cultivar (RT $7311 \mathrm{CL}$ ) grown in a DeWitt silt loam (Albaqualf). Six plastic tubs, filled with $21 \mathrm{~kg}$ of soil and manually seeded, were arranged in a completely random design with two replications of three water regime treatments: i) flooded, ii) saturated, but not flooded and, iii) moist soil (i.e., slightly below saturation). In each tub, a 30-cm-diameter base collar was installed to a depth of $12 \mathrm{~cm}$. Soil volumetric water content in the tubs was recorded daily, while above ground and root dry matter (DM) were collected at the end of the season. Methane, $\mathrm{N}_{2} \mathrm{O}$, and $\mathrm{CO}_{2}$ fluxes differed among water regimes over time $(P<0.05)$. Season-long $\mathrm{CH}_{4}$ and $\mathrm{CO}_{2}$ emissions differed among water regimes $(P<0.05)$ and were three and two times larger from the flooded-soil condition than from the moist-soil and nearly saturated conditions, respectively, while season-long $\mathrm{N}_{2} \mathrm{O}$ emissions were unaffected by water regime. Aboveground DM was more than two times greater $(P<0.05)$ from the flooded-soil than from the non-flooded treatments. Root DM was unaffected by water regime. Characterizing the effects of soil moisture content could improve the understanding of the dynamics that regulate production of greenhouse gases in rice production systems.
\end{abstract}

\section{Keywords}

Rice production, Arkansas, Greenhouse gas emissions

\section{Introduction}

As a semi-perennial, semi-aquatic grass, when grown in flooded-soil conditions, rice (Oryza sativa L.) is able to act as a conduit for gases from the soil to the atmosphere through aerenchyma tissue [1]. However, the large amount of water used to flood rice fields and the biochemical reactions that occur in the resulting anoxic environment, which are responsible for the production of methane $\left(\mathrm{CH}_{4}\right)$, require evaluation across different production techniques in order to determine the best management practices to maintain profitable yields and reduce greenhouse gas (GHG) emissions to the atmosphere [2].

Different water management and field preparation practices greatly affect the production and emissions of GHGs from rice fields [2]. Continuous flooding, intermittent flooding, and delayed flooding (DF), in combination with cultural practices, like conventional tillage (CT) or no-tillage (NT), have been studied to determine the environmental impact of these varying practices [2-4]. The drying process associated with alternate wet-dry (AWD) and DF water management schemes causes an increase in soil oxidation-reduction (redox) potential and favors oxidation and microbial reactions, such as the

*Corresponding author: Diego Della Lunga, Department of Crop, Soil, and Environmental Sciences, University of Arkansas, 115 Plant Sciences Building, Fayetteville, AR 72701, USA

Accepted: August 24, 2020

Published online: August 26, 2020

Citation: Della Lunga D, Brye KR, Roberts TL, et al. (2020) Water Management Effects on Trace Gas Emissions under Greenhouse Conditions from Direct-Seeded Hybrid Rice in a Silt-Loam Soil. J Rice Res Dev 3(1):95-102 
Citation: Della Lunga D, Brye KR, Roberts TL, et al. (2020) Water Management Effects on Trace Gas Emissions under Greenhouse Conditions from Direct-Seeded Hybrid Rice in a Silt-Loam Soil. J Rice Res Dev 3(1):95-102

nitrification of ammonium hydrolyzed from synthetic fertilizers (i.e., urea). As a result, $\mathrm{CH}_{4}$ emissions decrease, while nitrous oxide $\left(\mathrm{N}_{2} \mathrm{O}\right)$ emissions increase compared to emissions from continuously flooded conditions [3]. Furthermore, NT reduces soil erosion and increases organic matter and carbon (C) substrate that can increase the production of $\mathrm{N}_{2} \mathrm{O}$ in a rice field [4]. Nitrification-denitrification, methanogenesis-methanotrophy, and soil respiration are the main mechanisms responsible for the production of $\mathrm{N}_{2} \mathrm{O}, \mathrm{CH}_{4}$, and carbon dioxide $\left(\mathrm{CO}_{2}\right)$ respectively in the soil [4].

Nitrification is an aerobic, oxidative process that proceeds at an optimal rate when $60 \%$ of the soil pore space is filled with water (i.e., water-filled pore space), the soil temperature is between 20 and $30{ }^{\circ} \mathrm{C}$, and the soil $\mathrm{pH}$ is close to neutral (i.e., pH 7) [5]. Methanogenesis and methanotrophy are processes strongly affected by soil physical and chemical properties. Soil organic matter (SOM), $\mathrm{pH}$, temperature, redox potential, and soil texture are all interactive factors that impact the production and consumption of $\mathrm{CH}_{4}[6,7]$. Water management is considered the most relevant tool in order to suppress methanogenesis [8].

The ideal soil moisture content for SOM decomposition to occur at the most optimum rate is around $70 \%$ water-filled pore space, or near field capacity [9]. The sum of respiration from the rhizosphere and the microbial community in the pedosphere represents the amount of $\mathrm{CO}_{2}$ released from the soil and is defined as soil respiration [10]. Various soil parameters are correlated with the production and release of $\mathrm{CO}_{2}$ from the pedosphere [11]. Soil $\mathrm{pH}$, texture, moisture content and aeration, amount of organic substrate as SOM, and temperature determine the rate of decomposition and respiration, thus providing a valid index of $\mathrm{CO}_{2}$ produced [12] A strong, positive correlation between moisture content, up to a certain level, and soil respiration has been documented in several different ecosystems [12]. With the increasing water-shortage conditions in Arkansas, research on effective water use in rice production has been initiated $[13,14]$.

Studies on irrigation practices determined that furrow-irrigation (FI) systems reduced water usage by 41 to $48 \%$ compared to conventional irrigation $(\mathrm{Cl})$ practices and increased water-use efficiency (WUE), resulting in a reduction in the irrigation rate, evapotranspiration, and seepage due to the absence of a surface water layer [13]. The ferrous material in the soil was reduced under $\mathrm{FI}$ compared to $\mathrm{Cl}$, which benefitted root growth. Light penetration increased and the gas transport between the soil and the atmosphere was enhanced more in $\mathrm{Fl}$ than in $\mathrm{Cl}$ [13]. One of the greatest management challenges for a furrow-irrigated rice production system is the dynamic variability in the soil surface environment, where flooded (down-slope position), moist (mid-slope position), and semi-dry (up-slope position) conditions alternate and coexist at the different site positions within the same furrow-irrigated field [15]. Consequently, the large soil moisture fluctuations in a furrow-irrigated rice field may exacerbate GHG emissions, where rice has been specifically identified as a substantial source of $\mathrm{CH}_{4}$ emissions [12]. Following the introduc- tion of drought-resistant hybrids, furrow-irrigation practices have rapidly increased in Arkansas in the last decade, with a percent of total hectares under furrow-irrigation increasing from $0.3 \%$ in 2012 to more than 10\% in 2019 [16]. However, to date, very few studies have evaluated the environmental impact of the furrow-irrigated rice production system.

The objective of this study was to assess and quantify $\mathrm{CH}_{4}, \mathrm{~N}_{2} \mathrm{O}$, and $\mathrm{CO}_{2}$ released from a historically-rice-cultivated, silt-loam soil under direct-seeded conditions in the greenhouse and to evaluate the effects of water regime (i.e., moist conditions, near saturation, and flooded) on fluxes and growing-season emissions and emissions intensity. The water regime treatments were purposely chosen to simulate environmental conditions at the up- (moist conditions), mid- (near saturation), and down-slope (flooded) positions in a furrow-irrigated rice field. It was hypothesized that $\mathrm{CH}_{4}$ emissions will be greater in flooded than non-flooded treatments due to the development of anaerobic soil conditions, while $\mathrm{N}_{2} \mathrm{O}$ emissions will be greater from near-saturated than from moist-soil or flooded conditions due to a more optimal environment for nitrification and denitrification. It was hypothesized that $\mathrm{CO}_{2}$ emissions will be greater in moist-soil treatments due to more aerobic soil conditions.

\section{Material and Methods}

\section{Soil collection, preparation, and analyses}

This study was conducted between February and May 2019 in the greenhouse at the Agricultural Research and Extension Center (AREC), Fayetteville, AR. Six, 51-L plastic tubs (51 cm wide by $67 \mathrm{~cm}$ long by $15 \mathrm{~cm}$ deep) were placed on the same greenhouse bench under controlled ambient conditions. A daily temperature of $31{ }^{\circ} \mathrm{C}$ was maintained during a photoperiod of 14 hours using 1000-Watt heating lamps (Metalarc M1000/U/BT37, Silvanya, Wilmington, MA) installed at an initial distance of $25 \mathrm{~cm}$ from the top of the tubs. The height of the heating lamps was adjusted three times during the growing season to accommodate the growth of the rice plants. A secondary heating system kept the nocturnal temperature above $22^{\circ} \mathrm{C}$.

Each tub was filled with $21 \mathrm{~kg}$ of air-dried soil collected from the Rice Research and Extension Center $\left(34.46^{\circ} \mathrm{N}\right.$, $-91.46^{\circ} \mathrm{W}$ ) near Stuttgart in Arkansas County, AR. The soil was collected from the top $10 \mathrm{~cm}$ of a furrow-irrigated rice field that had been under cultivated agriculture for at least 15 years and was classified as DeWitt silt loam (fine, smectitic, thermic Typic Albaqualfs), which is a slowly permeable and slowly drained soil. The soil was sieved through a 5-mm mesh to simulate mixing by tillage and let dry for three days, after which the soil was manually leveled in each tub to result in a soil depth of at least $15 \mathrm{~cm}$. The six tubs were placed equidistant from each other on a single greenhouse bench. Stiff, wooded boards were placed beneath the tubs to level each tub to avoid non-uniform movement or accumulation of water in the tubs and to facilitate uniform soil settling after wetting.

Soil samples were collected from the top $10 \mathrm{~cm}$, before any water was added, with a $4.8-\mathrm{cm}$ diameter, stainless steel 
Citation: Della Lunga D, Brye KR, Roberts TL, et al. (2020) Water Management Effects on Trace Gas Emissions under Greenhouse Conditions from Direct-Seeded Hybrid Rice in a Silt-Loam Soil. J Rice Res Dev 3(1):95-102

core chamber for bulk density determination and chemical analyses. Soil samples were oven-dried at $70{ }^{\circ} \mathrm{C}$ for 48 hours, ground, and sieved through a $2-\mathrm{mm}$ mesh screen. Particle-size distribution was determined using a modified 12-hr hydrometer method [17]. Soil electrical conductivity (EC) and $\mathrm{pH}$ were measured potentiometrically in a 1:2 soil mass:water volume suspension. Soil organic matter concentration was determined by weight-loss-on-ignition after combustion at $360{ }^{\circ} \mathrm{C}$ for 2 hours. Total carbon (TC) and total nitrogen (TN) concentrations were determined by high-temperature combustions using a VarioMax $\mathrm{CN}$ analyzer (Elementar Americas Inc., Mt. Laurel, NJ; [18]). Extractable soil nutrient concentrations (i.e., $\mathrm{P}, \mathrm{K}, \mathrm{Ca}, \mathrm{Mg}, \mathrm{Fe}, \mathrm{Mn}, \mathrm{Na}, \mathrm{S}, \mathrm{Cu}$, and $\mathrm{Zn}$ ) were determined after extraction with Mehlich-3 extraction solution in a 1:10 soil mass:water volume ratio and analyzed by inductively coupled, argon-plasma spectrophotometry (ICAPS; [19]). Measured concentrations $\left(\mathrm{g} \mathrm{kg}^{-1}\right)$ were converted to contents $\left(\mathrm{Mg} \mathrm{ha}^{-1}\right.$ ) using the measured bulk density and $10-\mathrm{cm}$ sample depth interval.

\section{Sensor installation}

Volumetric soil water content and soil temperature were continuously measured throughout the growing season to evaluate environmental factors known to affect GHG production and emissions. One water content reflectometer (Model CS616, Campbell Scientific, Inc., Logan, UT) per tub was installed at the 12-cm depth, right before seeding, and connected to a CR1000 data logger (Campbell Scientific) that recorded data at 5-minute intervals and output data averages every hour. One thermocouple (Type E, chromel-constantan) was also installed at the $12-\mathrm{cm}$ depth, right before seeding, and connected to the data logger to record soil temperature at 5-minute intervals with averages output hourly. The data logger and enclosure that contained the data logger were placed in a central position on the bench between soil tubs.

\section{Plant establishment}

Tubs were manually seeded with the hybrid cultivar RT $7311 \mathrm{CL}$ (RiceTec, Alvin, TX) on February 7, 2019. Following University of Arkansas recommendations, 129 seeds $\mathrm{m}^{-2}$, or 23 seeds $\mathrm{m}^{-1}$ of row, were planted at a depth of $2 \mathrm{~cm}$ and at a spacing of one seed every $4.3 \mathrm{~cm}$, for a total of 24 seeds per tub and three rows that were perpendicular to the long side of the tub. Moist soil was used to cover the small holes that were made where the seeds were placed to facilitate proper germination.

From February 7 to March 6, 2019, all tubs were manually watered uniformly every day with tap water until the soil was visually wet, but not saturated. On March 7, 2019, the equivalent of $224 \mathrm{~kg} \mathrm{ha}^{-1}(6.3 \mathrm{~g})$ of nitrogen $(\mathrm{N})$ as $\mathrm{N}$-(n-butyl) thiophosphoric triamide (NBPT)-coated urea and the equivalent of $134 \mathrm{~kg} \mathrm{ha}^{-1}(3.8 \mathrm{~g}$ ) of potassium (K) as muriate of potash were manually, uniformly applied to the soil surface of each tub, in which the soil surface was somewhat dry because no irrigation water had been applied within the previous 24 hours. On March 8 and 9, 2019, each tub was flooded to a depth of $5 \mathrm{~cm}$ to allow the fertilizer to dissolve and penetrate into the soil.

\section{Base collar installation for gas flux measure- ments}

On March 11, 2019, a 30-cm diameter and 30-cm tall polyvinyl chloride (PVC) base collar was installed in each tub to a depth of $12 \mathrm{~cm}$. Base collars had a beveled bottom to facilitate installation and four, $12.5-\mathrm{mm}$ diameter holes drilled $12 \mathrm{~cm}$ from the beveled end to allow free movement of water into and out of the base collars. Each base collar contained portions of two rice rows and initially nine rice plants. On March 12, 2019, a fan with a 51-cm blade diameter (part\#G8058891, Lasko, West Chester, PA) was installed parallel to one of the shorter sides of the bench and kept at medium speed (500 $\mathrm{rpm}$ ) for the remainder of the study. The fan allowed for faster evaporation from the tubs by reducing the relative humidity immediately above the soil tubs. The fan also facilitated the movement of water through the soil depth, and limited the presence of standing water in the tubs especially after watering.

\section{Irrigation schemes}

The six tubs were arranged in a completely random design with two replications of three water regime treatments: i) flooded, ii) saturated, but not flooded and, iii) moist soil (i.e., slightly below saturation). Flooded conditions were established permanently on March 10, 2019 in two of the tubs, while two tubs were kept at a constant volumetric water content of $0.44 \mathrm{~cm}^{3} \mathrm{~cm}^{-3}$ (i.e., moist soil), and the last two tubs were kept at a constant volumetric water content of 0.56 $\mathrm{cm}^{3} \mathrm{~cm}^{-3}$ (i.e., saturation). The volumetric water content of each tub was checked once a day, between 1000 and 1300 hours, by connecting a mobile personal computer device (part\#83754, Campbell Scientific, Inc., Logan, UT) to the data logger to display the current reflectometer-measured values. The volumetric water content was converted to gravimetric water content using the measured bulk density and converted again to milliliters of water necessary to be added to each tub to reach the desired target volumetric water content (i.e., 0.44 or $0.56 \mathrm{~cm}^{3} \mathrm{~cm}^{-3}$ ). The appropriate volume of tap water was measured with a 1-L graduated cylinder and transferred to a 7.5-L watering can that was used to irrigate the tubs. The two flooded tubs were visually checked daily and the flood was maintained to at least a 5-cm deep. On March 26 [48 days after planting (DAP)], the equivalent of $112 \mathrm{~kg} \mathrm{ha}^{-1}(3.15 \mathrm{~g})$ of $\mathrm{N}$ as NBPT-coated urea and the equivalent of $44 \mathrm{~kg} \mathrm{ha}^{-1}(1 \mathrm{~g})$ of zinc $(\mathrm{Zn})$ as zinc sulfate were manually, uniformly applied to the flood water or the moist soil surface of each tub.

\section{Gas measurements}

On 13 different dates (i.e., 37, 41, 48, 50, 55, 62, 69, 76, $83,90,97,105$, and 112 DAP), gas sampling occurred between 0900 and 1000 hours. Before gas collection, a 30-cm diameter by $10-\mathrm{cm}$ tall cap was placed on top of the base collars and sealed with a rubber flap $[3,20,21]$. Each cap was equipped with a $2.5-\mathrm{cm}^{2}$ fan (MagLev GM1202PFV2-8, Sunon Inc., Brea, CA) powered by a 9-V battery installed on the bottom side of the cap $[3,20,21]$. On the side of each cap, a 15$\mathrm{cm}$ long, 0.63-cm inside-diameter copper refrigerator tube was mounted to establish pressure equilibrium between the 
Citation: Della Lunga D, Brye KR, Roberts TL, et al. (2020) Water Management Effects on Trace Gas Emissions under Greenhouse Conditions from Direct-Seeded Hybrid Rice in a Silt-Loam Soil. J Rice Res Dev 3(1):95-102

headspace inside the chamber and the outside environment $[3,20,21]$. Caps and extenders, used to accommodate the growth of the plants, were wrapped in reflective aluminum tape (Mylar metallized tape, CS Hyde, Lake Villa, IL) to minimize temperature increase and overheating of the chambers during gas sampling. Caps were also equipped with a septum (part \#73828A-RB, Voigt Global, Lawrence, KS) inserted in a $1.25-\mathrm{cm}$ diameter hole in the top of the cap. One of the caps had an additional septum inserted on the top to allow the insertion of a thermometer used to measure the temperature inside the sealed chamber during sampling.

Gas samples were collected at 20-minute intervals (i.e., 0, $20,40,60$ minutes) over a 1-hr period with a 20-mL syringe with a $0.5-\times 25-\mathrm{mm}$ needle [Beckton Dickson and Co (B-D), Franklin Lakes, NJ] that was inserted through the septum in the cap to collect a $20-\mathrm{mL}$ sample of fan-mixed, headspace gas. The gas sample was transferred to a pre-capped, $20-\mathrm{mm}$ headspace, crimp-cap (part \#5183-4479, Agilent Technologies, Santa Clara, CA), pre-evacuated, $10-\mathrm{mL}$ glass vial (part \#5182-0838, Agilent Technologies). The height of the chamber was measured from the soil surface or from the top of standing water for proper chamber volume determination.

Gas samples were analyzed with a Shimadzu GC-2014 gas chromatograph (GC; Shimadzu North America/Shimadzu Scientific Instruments Inc., Columbia, MD) using a flame ionization detector (FID) for $\mathrm{CH}_{4}$ and $\mathrm{CO}_{2}$. Nitrous oxide was analyzed using an electron capture detector (ECD). Linear regression was used to calculate the gas flux $\left(\mu \mathrm{L} \mathrm{m}^{-2} \mathrm{~min}^{-1} ;\right.$ [22]) as the change in concentration over time (i.e., the slope of the regression line), while linear interpolation was used to determine seasonal emissions $\left(\mathrm{kg} \mathrm{ha}^{-1}\right.$ season $\left.^{-1}\right)$ on a chamber-by-chamber basis. At the end of the experiment (i.e., 114 DAP), aboveground and root biomass were collected from inside the collars, dried for 7 days in a forced-draft oven at 55 ${ }^{\circ} \mathrm{C}$ and weighed. Emissions intensities were also calculated on a chamber-by-chamber basis by dividing the season-long gas emissions by the aboveground or root dry matter (DM).

\section{Statistical analyses}

Based on a completely random experimental design, a two-factor analysis of variance (ANOVA) was performed using the PROC GLIMMIX in SAS (version 9.4, SAS Institute, Inc., Cary, NC) to evaluate the effect of water regime (i.e., moist, near saturated, and flooded), time (i.e., DAP), and their interaction on gas fluxes (i.e., $\mathrm{CH}_{4}, \mathrm{~N}_{2} \mathrm{O}$, and $\mathrm{CO}_{2}$ ). A separate ANOVA was conducted to evaluate the effect of water regime on season-long GHG emissions and aboveground and root dry matter. Significance was judged at the 0.05 level for all statistical tests.

\section{Results and Discussion}

\section{Initial soil properties}

Soil particle-size analyses confirmed a silt-loam textural class with $0.07 \mathrm{~g} \mathrm{~g}^{-1}$ clay (Table 1$)$. The relatively low bulk density $\left(1.10 \mathrm{~g} \mathrm{~cm}^{-3}\right)$ had an associated total porosity of $0.58 \mathrm{~cm}^{3}$ $\mathrm{cm}^{-3}$ (Table 1) before settling after water was added to the tubs. Soil $\mathrm{pH}$ was neutral ( $\mathrm{pH} 7)$, which was slightly above the
Table 1: Summary of initial physical and chemical properties of the soil used for the greenhouse experiment.

\begin{tabular}{|c|c|}
\hline Soil Property & Mean ( \pm standard error) \\
\hline Sand $\left(\mathrm{g} \mathrm{g}^{-1}\right)$ & $0.34(<0.01)$ \\
\hline Silt $\left(\mathrm{g} \mathrm{g}^{-1}\right)$ & $0.59(<0.01)$ \\
\hline Clay $\left(\mathrm{g} \mathrm{g}^{-1}\right)$ & $0.07(<0.01)$ \\
\hline Bulk density $\left(\mathrm{g} \mathrm{cm}^{-3}\right)$ & $1.10(0.01)$ \\
\hline $\mathrm{pH}$ & $7.00(0.03)$ \\
\hline Electrical conductivity $\left(\mathrm{dS} \mathrm{m}^{-1}\right.$ ) & $0.90(<0.01)$ \\
\hline \multicolumn{2}{|l|}{ Extractable soil nutrients $\left(\mathrm{Mg} \mathrm{ha}^{-1}\right)$} \\
\hline Phosphorus & $0.06(<0.01)$ \\
\hline Potassium & $0.19(0.02)$ \\
\hline Calcium & $5.68(0.02)$ \\
\hline Magnesium & $0.15(<0.01)$ \\
\hline Sulfur & $0.05(<0.01)$ \\
\hline Sodium & $0.09(<0.01)$ \\
\hline Iron & $0.24(<0.01)$ \\
\hline Manganese & $0.15(<0.01)$ \\
\hline Zinc & $0.01(<0.01)$ \\
\hline Soil organic matter $\left(\mathrm{Mg} \mathrm{ha}^{-1}\right)$ & $33.4(0.4)$ \\
\hline Total carbon (Mg ha-1) & $13.2(0.3)$ \\
\hline Total nitrogen $\left(\mathrm{Mg} \mathrm{ha}^{-1}\right)$ & $1.7(0.1)$ \\
\hline Carbon:Nitrogen ratio & $7.6(0.2)$ \\
\hline Total carbon:soil organic matter ratio & $0.4(<0.1)$ \\
\hline $\begin{array}{l}\text { Total nitrogen:soil organic matter } \\
\text { ratio }\end{array}$ & $0.05(<0.01)$ \\
\hline
\end{tabular}

$\sim 5.0$ to $6.75 \mathrm{pH}$ range for optimal rice growth (Table 1) [23]. Initial soil-test $\mathrm{P}$ and $\mathrm{K}$ were above optimum ( $>50 \mathrm{mg} \mathrm{kg}^{-1}$ ) and optimum (131 to $175 \mathrm{mg} \mathrm{kg}^{-1}$ ), respectively, while soil Ca, Mg, $\mathrm{S}$, and $\mathrm{Mn}$ were also all above the low soil-test levels, the only category given for soil $\mathrm{Ca}, \mathrm{Mg}, \mathrm{S}$, and $\mathrm{Mn}$ concentrations for fertilizer recommendations for rice grown in Arkansas [24]. Soil-test $\mathrm{Zn}$ was the only potential element, with a concentration in the medium category ( 3.1 to $4 \mathrm{mg} \mathrm{kg}^{-1}$ ), that could have caused a deficiency during the growing season (Table 1 ). The SOM concentration was at the upper end of the common range of 2.1 to $3.6 \%$ determined in tilled agricultural fields in the top $10 \mathrm{~cm}$ in Arkansas [22]. The low C: $\mathrm{N}$ ratio indicated an environment where decomposition and mineralization of inorganic-N was likely occurring rapidly (Table 1) [10].

\section{Gas fluxes}

Methane fluxes numerically peaked at 112 DAP in the flooded and nearly saturated $\left(0.56 \mathrm{~cm}^{3} \mathrm{~cm}^{-3}\right)$ conditions, while the moist-soil condition $\left(0.44 \mathrm{~cm}^{3} \mathrm{~cm}^{-3}\right)$ numerically peaked at 90 DAP (Figure 1). Several studies recorded $\mathrm{CH}_{4}$ peaks later in the season in flooded conditions due to root exudates and litter [25-28]. Additionally, the continuous addition of water most likely created anaerobic and reducing conditions in micro-site portions of the soil in the moist and nearly 


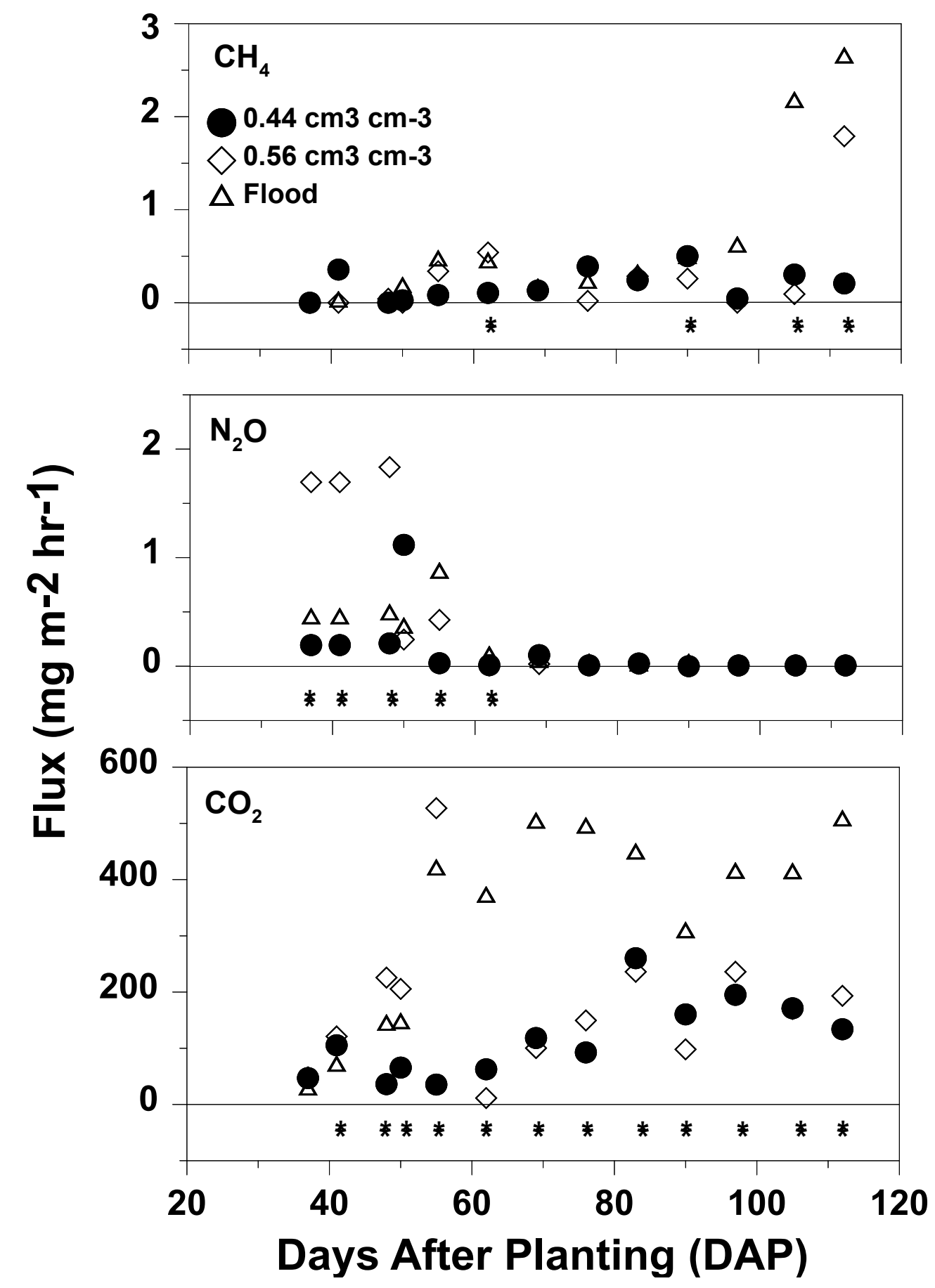

Figure 1: Methane $\left(\mathrm{CH}_{4}\right)$, nitrous oxide $\left(\mathrm{N}_{2} \mathrm{O}\right)$, and carbon dioxide $\left(\mathrm{CO}_{2}\right)$ fluxed over time [days after planting (DAP)] among water regimes during the 2019 growing season in the greenhouse. Days after planting marked with an asterisk $\left(^{*}\right)$ indicate a significant difference in fluxes among the water regimes on that date.

saturated water regimes. In contrast, $\mathrm{N}_{2} \mathrm{O}$ fluxes numerically peaked at 48, 50, and 55 DAP in nearly saturated, moist-soil, and flooded-soil conditions, respectively (Figure 1). Peak $\mathrm{N}_{2} \mathrm{O}$ fluxes were most likely related to the fertilizer-N application at 48 DAP that stimulated microbial activity and denitrification. The different and delayed response to the application of fertilizer- $\mathrm{N}$ was due to the different moisture contents among water regimes that created different interactions between aerobic-anaerobic layers. Methane and $\mathrm{N}_{2} \mathrm{O}$ fluxes had nearly opposite trends over time (Figure 1). Carbon dioxide fluxes numerically peaked at 83,55 , and 112 DAP in moist-soil, nearly saturated, and flooded-soil conditions respectively, when aboveground biomass was maximal and root and microbial respiration were also likely maximal (Figure 1).

Methane, $\mathrm{N}_{2} \mathrm{O}$, and $\mathrm{CO}_{2}$ fluxes differed among water regimes over time (Table 2). Evaluation showed that 95\% (74 out of 78) of individual $\mathrm{CH}_{4}$ fluxes did not differ from zero. The remaining 5\% (4 out of 78 ) individual $\mathrm{CH}_{4}$ fluxes that differed from zero occurred from the flooded-soil treatment at 97, 105 , and 112 DAP, except for one flux from the nearly satu- 
Citation: Della Lunga D, Brye KR, Roberts TL, et al. (2020) Water Management Effects on Trace Gas Emissions under Greenhouse Conditions from Direct-Seeded Hybrid Rice in a Silt-Loam Soil. J Rice Res Dev 3(1):95-102

Table 2: Analysis of variance summary of the effects of time (days after planting), water regime, and their interaction on methane, nitrous oxide, and carbon dioxide fluxes during the 2019 growing season in the greenhouse.

\begin{tabular}{|c|c|c|c|}
\hline Source of Variation & Methane & Nitrous Oxide & Carbon Dioxide \\
\hline & & $<$ & $<0.01$ \\
\hline Time & $<0.01$ & $<0.01$ & 0.03 \\
\hline Water regime & 0.10 & 0.29 & $<0.01$ \\
\hline
\end{tabular}

Table 3: Summary of aboveground and root dry matter among water regimes $(n=2)$.

\begin{tabular}{|c|c|c|}
\hline Water Regime & Aboveground Dry Matter (Mg ha $\left.{ }^{-1}\right)$ & Root Dry Matter $\left(\mathrm{Mg} \mathrm{ha}{ }^{-1}\right)$ \\
\hline $0.44 \mathrm{~cm}^{3} \mathrm{~cm}^{-3}$ & $15.1^{\mathrm{bt}}$ & $19.3^{\mathrm{a}}$ \\
\hline $0.56 \mathrm{~cm}^{3} \mathrm{~cm}^{-3}$ & $16.6^{\mathrm{b}}$ & $31.3^{\mathrm{a}}$ \\
\hline Flood & $32.6^{\mathrm{a}}$ & $54.0^{\mathrm{a}}$ \\
\hline
\end{tabular}

${ }^{\dagger}$ Means in the same column followed by different letters are different at $\mathrm{P}<0.05$.

Table 4: Summary of methane $\left(\mathrm{CH}_{4}\right)$, nitrous oxide $\left(\mathrm{N}_{2} \mathrm{O}\right)$, and carbon dixoide $\left(\mathrm{CO}_{2}\right)$ emissions and emissions intensity $(n=2)$ among the different water regimes during the 2019 growing season in the greenhouse.

\begin{tabular}{|c|c|c|c|}
\hline \multirow[b]{2}{*}{ Gas/Emissions Property } & \multicolumn{3}{|c|}{ Water Regime } \\
\hline & $0.44 \mathrm{~cm}^{3} \mathrm{~cm}^{-3}$ & $0.56 \mathrm{~cm}^{3} \mathrm{~cm}^{-3}$ & Flood \\
\hline \multicolumn{4}{|l|}{ Methane } \\
\hline Emissions ( $\mathrm{kg} \mathrm{CH}_{4}-\mathrm{C} \mathrm{ha}^{-1}$ season $^{-1}$ ) & $3.5^{b^{+}}$ & $4.1^{\mathrm{b}}$ & $10.2^{\mathrm{a}}$ \\
\hline Intensity ( $\mathrm{kg} \mathrm{CH}_{4}-\mathrm{C} \mathrm{Mg}$ aboveground dry matter ${ }^{-1}$ ) & $0.23^{\mathrm{a}}$ & $0.25^{\mathrm{a}}$ & $0.31^{\mathrm{a}}$ \\
\hline Intensity ( $\mathrm{kg} \mathrm{CH}_{4}-\mathrm{C} \mathrm{Mg}$ root dry matter ${ }^{-1}$ ) & $0.18^{a}$ & $0.13^{\mathrm{a}}$ & $0.19^{\mathrm{a}}$ \\
\hline \multicolumn{4}{|l|}{ Nitrous oxide } \\
\hline Emissions ( $\mathrm{kg} \mathrm{N}_{2} \mathrm{O}-\mathrm{N}$ ha $^{-1}$ season $^{-1}$ ) & $1.9^{\mathrm{a}}$ & $6.2^{\mathrm{a}}$ & $3.7^{\mathrm{a}}$ \\
\hline Intensity ( $\mathrm{kg} \mathrm{N}_{2} \mathrm{O}-\mathrm{N} \mathrm{Mg}$ aboveground dry matter ${ }^{-1}$ ) & $0.12^{\mathrm{a}}$ & $0.37^{a}$ & $0.11^{\mathrm{a}}$ \\
\hline Intensity ( $\mathrm{kg} \mathrm{N}_{2} \mathrm{O}-\mathrm{N} \mathrm{Mg}$ root dry matter ${ }^{-1}$ ) & $0.10^{\mathrm{a}}$ & $0.20^{\mathrm{a}}$ & $0.10^{\mathrm{a}}$ \\
\hline \multicolumn{4}{|l|}{ Carbon dioxide } \\
\hline Emissions $\left(\mathrm{kg} \mathrm{CO}_{2}-\mathrm{C}_{\text {ha-1 }}\right.$ season $\left.^{-1}\right)$ & $2234^{b}$ & $3235^{b}$ & $6365^{\mathrm{a}}$ \\
\hline Intensity ( $\mathrm{kg} \mathrm{CO}_{2}-\mathrm{C} \mathrm{Mg}$ aboveground dry matter-1) & $148^{\mathrm{a}}$ & $195^{\mathrm{a}}$ & $195^{\mathrm{a}}$ \\
\hline Intensity ( $\mathrm{kg} \mathrm{CO}_{2}-\mathrm{C} \mathrm{Mg}$ root dry matter $\left.{ }^{-1}\right)$ & $116^{\mathrm{a}}$ & $103^{\mathrm{a}}$ & $118^{\mathrm{a}}$ \\
\hline
\end{tabular}

${ }^{+}$Means in the same row followed by different letters are different at $P<0.05$.

rated treatment (i.e., $0.56 \mathrm{~cm}^{3} \mathrm{~cm}^{-3}$ ) that occurred at $112 \mathrm{DAP}$ (Figure 1). Similar to $\mathrm{CH}_{4}$, only $6.4 \%$ (5 out of 78 ) of $\mathrm{N}_{2} \mathrm{O}$ fluxes differed from zero and were all measured in the first half of the growing season, specifically at $37,41,48,50$, and 55 DAP (Figure 1). The $\mathrm{N}_{2} \mathrm{O}$ fluxes at 37,41 , and 48 DAP occurred from the nearly saturated water regime, while the $\mathrm{N}_{2} \mathrm{O}$ fluxes at 50 and 55 DAP occurred from the moist-soil and flooded-soil condition, respectively. In contrast to $\mathrm{CH}_{4}$ and $\mathrm{N}_{2} \mathrm{O}, 27 \%$ of the $\mathrm{CO}_{2}$ fluxes differed from zero, where most occurred during the second half of the growing season at 48, 50, 55, 62, 69, $76,83,90,97,105$, and 112 DAP and most occurred from the nearly saturated (i.e., 48, 50, 55, 76, 83, 97, 105, and 112 DAP) and flooded-soil (i.e., 55, 62, 69, 76, 83, 90, 97, 105, and 112 DAP) conditions (Figure 1 ).

\section{Plant response}

End-of-the-season aboveground rice DM differed ( $P=$ 0.03 ) among water regimes (Table 3 ). Aboveground DM was more than two times greater from the flooded-soil $(32.6 \mathrm{Mg}$ $\mathrm{ha}^{-1}$ ) than from the non-flooded treatments, which did not differ and averaged $15.8 \mathrm{Mg}^{-1}$ (Table 3). Though root DM ranged from $19.3 \mathrm{Mg} \mathrm{ha}^{-1}$ in the moist-soil to $54.0 \mathrm{Mg} \mathrm{ha}^{-1}$ in the flooded-soil condition (Table 3), root DM was unaffected by water regime due to large measured variability.

\section{Gas emissions}

Season-long $\mathrm{CH}_{4}$ emissions differed among water regimes $(P=0.05)$ and were larger from the flooded-soil condition (10.2 kg CH $\mathrm{Cha}^{-1}$ season $\left.^{-1}\right)$ than from the moist-soil $(3.5 \mathrm{~kg}$ $\mathrm{CH}_{4}-\mathrm{Cha}^{-1}$ season $\left.^{-1}\right)$ and nearly saturated $\left(4.1 \mathrm{~kg} \mathrm{CH}_{4}-\mathrm{Cha}^{-1}\right.$ season $^{-1}$ ) conditions (Table 4). As was hypothesized, the flooded-soil conditions produced greater season-long $\mathrm{CH}_{4}$ emissions due to the prolonged reducing conditions that likely developed to facilitate methanogenesis [28].

In contrast to $\mathrm{CH}_{4}$ emissions, $\mathrm{N}_{2} \mathrm{O}$ emissions were unaffect- 
Citation: Della Lunga D, Brye KR, Roberts TL, et al. (2020) Water Management Effects on Trace Gas Emissions under Greenhouse Conditions from Direct-Seeded Hybrid Rice in a Silt-Loam Soil. J Rice Res Dev 3(1):95-102

ed by water regime $(P>0.05)$ and ranged from $1.9 \mathrm{~kg} \mathrm{~N} 2 \mathrm{O}-\mathrm{N}$ ha $^{-1}$ season $^{-1}$ from the moist-soil to $6.2 \mathrm{~kg} \mathrm{~N}_{2} \mathrm{O}-\mathrm{N} \mathrm{ha}^{-1}$ season $^{-1}$ from the nearly saturated condition and averaged $3.9 \mathrm{~kg}$ $\mathrm{N}_{2} \mathrm{O}-\mathrm{N}$ ha-1 season $^{-1}$ across all three water regimes (Table 4). The nearly saturated soil conditions (i.e., $0.56 \mathrm{~cm}^{3} \mathrm{~cm}^{-3}$ ), in addition to the presence of an oxidative layer at the soil surface, likely created the most optimal conditions for denitrification among the water regimes, while the drier soil conditions in the moist-soil treatment (i.e., $0.44 \mathrm{~cm}^{3} \mathrm{~cm}^{-3}$ ) and the lack of an oxidative layer at the soil surface in flooded-soil condition likely inhibited the production of $\mathrm{N}_{2} \mathrm{O}$ [3].

Previous research on $\mathrm{N}_{2} \mathrm{O}$ emissions in incubation studies showed the correlation between soil moisture content and denitrification to affect $\mathrm{N}_{2} \mathrm{O}$ production and release [29]. Nitrous oxide production increased steadily when the soil moisture content increased from 40 to $70 \%$ water-filled pore space (WFPS) [29]. Previous studies reported peak $\mathrm{N}_{2} \mathrm{O}$ emissions when the volumetric soil water content approached $80 \%$ of field moisture capacity [29]. Soil water content differentially influences bacterial communities responsible for the production and release of $\mathrm{CH}_{4}$ and $\mathrm{N}_{2} \mathrm{O}$, where increasing soil water content acts like a switch between $\mathrm{N}_{2} \mathrm{O}$ production in more aerobic conditions to $\mathrm{CH}_{4}$ production in strictly anaerobic conditions [3].

Similar to $\mathrm{CH}_{4}, \mathrm{CO}_{2}$ emissions differed among water regimes $(P=0.04)$ and were larger from the flooded-soil conditions $6365 \mathrm{~kg} \mathrm{CO}_{2}-\mathrm{C}^{-1}$ season $^{-1}$ than from moist-soil (3235 kg $\mathrm{CO}_{2}-\mathrm{C} \mathrm{ha}^{-1}$ season $\left.^{-1}\right)$ and nearly saturated (3235 $\mathrm{kg} \mathrm{CO}_{2}-\mathrm{Cha}^{-1}$ season $^{-1}$ ) conditions, which did not differ (Table 4). Carbon dioxide emissions were most likely related to the trends in root biomass production (Table 3 ) that participated in respiration.

Methane, $\mathrm{N}_{2} \mathrm{O}$, and $\mathrm{CO}_{2}$ emissions intensities, calculated on an aboveground- and root-DM basis, did not differ among water regimes (Table 4) due to large variability associated with both gas fluxes and aboveground and root DM. Considering that each treatment included in the study received similar fertilizer applications (i.e., N, P, K), and that only one soil (i.e., Dewitt silt loam) was used as growing medium, the absence of a significant difference in emissions intensities among the different water regimes suggests the relevance of rice plants in production and release of $\mathrm{CH}_{4}, \mathrm{~N}_{2} \mathrm{O}$, and $\mathrm{CO}_{2}$ [30].

\section{Conclusions}

Differential irrigation regimes in rice production have been shown to have a significant and immediate impact on GHG emissions. A comprehensive and mechanistic understanding of how environmental parameters (i.e., water management) interact with GHG production and release can lead to the evaluation and design of new management practices, especially in rice production systems, where, to date, numerous studies are focusing on mitigation and abatement techniques. The results of this study demonstrated the large influence that soil moisture content has on GHG emissions, specifically $\mathrm{CH}_{4}, \mathrm{~N}_{2} \mathrm{O}$, and $\mathrm{CO}_{2}$, for estimating environmental impacts of rice production systems. The differences in season-long GHG emissions between water regimes was substantial, thus will likely affect the estimated global warming potentials associat- ed with the various water regimes evaluated. Characterizing the effects of various environmental factors, like soil moisture content, could improve the understanding of the dynamics that regulate GHG production and release in rice production systems. Studies and research supplement federal agencies, such as, but not limited to, the U.S. Department of Agriculture (USDA), U.S. Geological Survey (USGS), and National Oceanic and Atmospheric Administration (NOAA), with field and laboratory data that are used to corroborate GHG estimations and rice cultivation studies are not an exception [31]. The most common approach is to utilize data, almost exclusively, from rice fields under flooded conditions [31]. However, an approach that considers the variability among rice production systems could improve on the difficult task of estimating GHG emissions from the agricultural sector, but this requires actual field data, which studies such as the current one provides.

\section{Acknowledgements}

The authors gratefully acknowledge greenhouse assistance provided by Dr. Rick Norman, Jordan Slayden, and Ryan Greenfield.

\section{References}

1. Yan X, Shi S, Du L, et al. (2000) Pathways of $\mathrm{N}_{2} \mathrm{O}$ emission in rice paddy soil. Soil Biology and Biochemistry 32: 437-440.

2. Pittelkow CM, Adviento-Borbe MA, Hill JE, et al. (2013) Yieldscaled global warming potential of annual nitrous oxide and methane emission from continuously flooded rice in response to nitrogen input. Agric Ecosyst Environ 177: 10-20.

3. Rector C, Brye KR, Humphreys J, et al. (2018) Tillage and coated-urea effects on nitrous oxide emissions from direct-seeded, delayed-flood rice production in Arkansas. J Rice Res Dev 1: 2537.

4. Liu XJ, Mosier AR, Halvorson AD, et al. (2006) The impact of nitrogen placement and tillage on $\mathrm{NO}, \mathrm{N}_{2} \mathrm{O}, \mathrm{CH}_{4}$, and $\mathrm{CO}_{2}$ fluxes from a clay loam soil. Plant Soil 280: 177-188.

5. Lai TV, Denton MD (2017) $\mathrm{N}_{2} \mathrm{O}$ and $\mathrm{N}_{2}$ emissions from denitrification respond differently to temperature and nitrogen supply. J Soils Sedi 18: 1548-1557.

6. Oo AZ, Bellingrath-Kimura KTW, Bellingrath-Kimura SD (2015) Within field spatial variation in methane emissions from lowland rice in Myanmar. Springer Plus 4: 145-155.

7. Brye KR, Rogers CW, Smartt AD, et al. (2013) Soil texture effects on methane emissions from direct-seeded, delayed-flood rice production in Arkansas. Soil Sci 178: 519-529.

8. Malyan SK, Bhatia A, Kumar A, et al. (2016) Methane production, oxidation and mitigation: A mechanistic understanding and comprehensive evaluation of influencing factors. Sci Total Environ 572: 874-896.

9. Eswaran H, Reich PF, Kimble J, et al. (2000) Global carbon stocks. In: Lal R, Kimble J, Levine E, Stewart BA, Global climate change and pedogenic carbonates. Lewis Publisher, Boca Raton, FL, 1526.

10. Brady NC, Weil RR (2008) The Nature and Properties of Soils. (14 ${ }^{\text {th }}$ edn), Pearson Prentice Hall, Upper Saddle River, NJ, 975.

11. Motschenbacher JM, Brye KR, Anders MM, et al. (2015) Daily soil surface $\mathrm{CO}_{2}$ flux during non-flooded periods in flood-irrigated 
Citation: Della Lunga D, Brye KR, Roberts TL, et al. (2020) Water Management Effects on Trace Gas Emissions under Greenhouse Conditions from Direct-Seeded Hybrid Rice in a Silt-Loam Soil. J Rice Res Dev 3(1):95-102

rice rotations. Agron Sustain Dev 35: 771-782.

12. (2019) Global warming of $1.5^{\circ} \mathrm{C}$ : An IPCC Special Report on the impacts of global warming of $1.5^{\circ} \mathrm{C}$ above pre-industrial levels and related global greenhouse gas emission pathways, in the context of strengthening the global response to the threat of climate change, sustainable development, and efforts to eradicate poverty. Intergovernmental Panel on Climate Change (IPCC), Cambridge University Press, Cambridge, UK and NY, USA.

13. He C (2010) Effects of furrow irrigation on the growth, production, and water use efficiency of direct sowing rice. Sci Word J 10: $1483-1497$

14. United States Geological Survey (USGS) (2010) Water levels and selected water-quality conditions in the Mississippi river valley alluvial aquifer in Eastern Arkansas, 2008. US Geological Survey.

15. Della Lunga D, Brye KR, Slayden JM, et al. (2020) Soil moisture, temperature, and oxidation-reduction potential fluctuations across a furrow-irrigated rice field on a silt-loam soil. J Rice Res Dev.

16. Hardke JT (2020) Furrow-irrigated rice handbook. University of Arkansas, Division of Agriculture, Cooperative Extension Service, Fayetteville, AR, 1-38.

17. Gee GW, Or D (2002) Particle-size analysis. In: Dane JH, Topp GC, Method of soil analysis. Part 4: Physical methods. (1 $1^{\text {st }}$ edn), Soil Science Society of America, Madison, WI, 255-293.

18. Nelson DW, Sommers LE (1996) Total carbon, organic carbon, and organic matter. In: DL Sparks, AL Page, PA Helmke, et al. Methods of soil analysis. Part 3: Chemical analysis. ( $3^{\text {rd }}$ edn), Soil Science Society of America, Madison, WI, 961-1010.

19. Tucker MR (1992) Determination of phosphorus by Mehlich 3 extraction. In: SJ Donohue, Soil and media diagnostic procedures for the southern region of the United Sates. Virginia Agricultural Experiment Station, Blacksburg, VA, 6-8.

20. Rogers CW, Brye KR, Smartt AD, et al. (2014) Cultivar and previous crop effects on methane emissions from drill-seeded, delayed-flood rice production on a silt-loam soil. Soil Sci 179: 28-36.

21. Smartt AD, Brye KR, Rogers CW, et al. (2015) Chamber size ef- fects on methane emissions from rice production. Open J Soil Sci 5: 227-235.

22. Venterea RT (2010) Simplified method for quantifying theoretical underestimation of chamber-based trace gas fluxes. J Environ Qual 39: 126-135.

23. Havlin JL, Tisdale SL, Nelson WL, et al. (2014) Soil fertility and fertilizers: An introduction to nutrient management. ( $8^{\text {th }}$ edn), Pearson Education Inc, Upper Saddle River, NJ, 516.

24. Roberts TL, Slaton NA, Wilson CJ, et al. (2018) Soil fertility. In: JT Hardke, Rice Production Handbook. University of Arkansas, Division of Agriculture, Cooperative Extension Service, Misc Pub, Fayetteville, AR, 69-101.

25. Brye KR, Pirani AL (2005) Native soil quality and the effects of tillage in the Grand Prairie region of eastern Arkansas. Am Midl Nat 154: 28-41.

26. Gogoi N, Baruah KK, Gogoi B, et al. (2005) Methane emission characteristics and its relations with plant and soil parameters under irrigated rice ecosystem of northeast India. Chemosphere 59: 1677-1684.

27. Bossio DA, Horwarth WR, Mutters RG, et al. (1999) Methane pool and flux dynamics in a rice field following straw incorporation. Soil Biol Biochem 31: 1313-1322.

28. Pittelkow CA, Linquist BA, Lundy ME, et al. (2015) When does notill yield more? A global analysis. Field Crops Res. 183: 156-168.

29. Nataningtyas DR, Morita S, Hatano R (2017) Effects of soil water content and grass recycling on $\mathrm{N}_{2} \mathrm{O}$ emission in a urban lawn under laboratory incubation study. Dev Chem Edu 1911: 231-236.

30. Arenas-Calle LN, Whitfield S, Challinor AJ (2019) A climate smartness index (CSI) based on greenhouse gas intensity and water productivity: Applicationto irrigated rice Front Sustai. Food Syst 3: 1-13.

31. United States Environmental Protection Agency (USEPA) (2020) Inventory of US greenhouse gas emissions and sinks: 1990-2018.

DOI: $10.36959 / 973 / 426$

Copyright: (C) 2020 Lunga DD, et al. This is an open-access article distributed under the terms of the Creative Commons Attribution License, which permits unrestricted use, distribution, and reproduction in any medium, provided the original author and source are credited. 